\section{From STEM to PAVAM: A unified arts strategy for innovation, industrial and regional policy}

Industry and Higher Education

2021, Vol. 0(0) I-14

(C) The Author(s) 2021

(c) (i) \$

Article reuse guidelines:

sagepub.com/journals-permissions

DOI: 10.1 | 77/095042222। I044076

journals.sagepub.com/home/ihe

(S)AGE

\author{
Henry Etzkowitz \\ International Triple Helix Institute, Palo Alto, CA, USA \\ Leila Maria Kehl \\ Birkbeck, University of London, London, UK \\ Tatiana Schofield \\ Royal College of Art, London, UK
}

\begin{abstract}
The potential of the arts and sciences for economic and social development is under conceptualized. However, the recent development of STEM (science, technology, engineering, and mathematics), justifying increased support for training in the sciences, shows a parallel pathway forward for the arts. The arts are increasingly relevant to the economy, amenable to policy influence as well as an area of human activity in their own right. The authors posit a unified arts framework: PAVAM (performing arts, visual arts, and music), complementing STEM as the basis for a strategy of arts-based interdisciplinary "industrial" policy making. The growing salience of the arts as an industrial sector in the UK and USA is shown. By identifying sources and pathways of value creation from the arts, clear entry points for policy action become identifiable to promote innovation, entrepreneurship, and economic development. Comparative case studies suggest a typology of the arts' potential as sources of creativity, innovation, and regional economic development.
\end{abstract}

\title{
Keywords
}

Industrial policy, arts economic value, cross-disciplinary innovation, PAVAM

Interaction among the Triple Helix of industry, government and university is a significant source of innovation (Etzkowitz and Zhou, 2017), but what should be included in the industrial helix has never been precisely defined. Although not necessarily the artist's intention, the generation of spillover effects from artistic production, performance, and display is increasingly recognized as a factor in local and regional economic development. For example, positive economic effects arose through visitors from afar and from the sale of memorial objects and catalogues at Banksy's "Dismaland," a dystopian pop-up art reinterpretation of Disneyland. Thus, "Local authorities, who routinely had his graffiti painted over a decade ago, now recognize their value and promote their expression. The local North Somerset Council said it was behind Dismaland, mindful of a show in nearby Bristol that attracted more than 300,000 fans from around the world in 2009." (Sandle, 2015).
The denigrated graffiti or nickelodeon of one era is another's high art and museum-worthy cultural heritage, a source of social and emotional bonds as well as a potential economic resource (Pizzitola, 2002).

The iconic emblem of American motion picture company Metro Goldwyn Mayer, ARS GRATIA ARTIS ringing a roaring lion's head at the start of each film, exemplifies a contentious debate about art as pure self-expression (Collingwood, 1925) and art as "an adequate expression to convey it to as many souls as possible" (Sand, 2009, p. 241). The collaborative production of a motion picture exemplifies this tension. Involving various arts, crafts, and business skills, their articulation encourages innovation and

\section{Corresponding author:}

Tatiana Schofield, Royal College of Art - Research and Innovation, Kensington Gore, London SW7 2EU, UK.

Email: tatiana.schofield@rca.ac.uk 
creativity in the development of a significant industry (Schatz, 1988). Heretofore perceived primarily as a public resource consumer, the arts are increasingly seen as a generator of economic and social development. As industrial society recedes, the arts may be expected to play an even greater role in post-industrial society, not only through automation-induced expectation of their growth as a leisure time pursuit but as a burgeoning profession. Indeed, the labor intensity of the arts is a social advantage, viewed in terms of employment, in an era in which robotics and AI displace routine physical and intellectual tasks.

The fraught relationship of the arts to each other and to the economy and society is an increasingly significant policy issue. Nevertheless, policy lags opportunity and tends to over-focus on visible signs of innovation and creativity, like science parks and theater complexes, rather than focusing on investing directly in encouraging creators at the early stages of value creation (Etzkowitz and Zhou, 2018). Recognition of the collectivity of science and engineering disciplines as STEM (science, technology, engineering, and mathematics) played a significant part in upgrading support for education and training in those fields. Facing a similar gap for the arts disciplines, we propose PAVAM (performing arts, visual arts, and music), summarizing a range of art disciplines as an entity in their own right, complementary to STEM, which also enhances science-led innovation through imaginative and critical human-focused approaches. ${ }^{1}$

\section{Research questions and method}

The PAVAM thesis addresses the following issues:

(1) How can the development of a unified framework for arts policy making and practice, comparable to STEM for the sciences, be institutionalized and legitimated?

(2) What can the analysis of specific cases of arts economic development show us about future innovation potential of the arts?

(3) Where can we learn from existing arts economic and policy studies to shape a model for arts industrial policy making?

In subsequent sections of this paper, we explore how arts connect to technology and science as well as perform innovation in their own right. A typology of the sources of the economic impact of the arts is inferred from comparative case studies, demonstrating the variety of ways in which arts contribute to the economy. On this base, we explore policy ideas and practical suggestions to enhance their economic and social impact in different contexts. Eschewing dichotomy - commercial use on the one edge and cultural on the other-in favor of continuum, allowed a mapping tool showing the proximity and relevance of artistic production to the economy.

Missing elements in the specific pathways of value creation in the creative sector, which overlap with software and advertising, indicate the need to obtain in-depth data on the economic impact originating in PAVAM activities. Thus, a qualitative approach, elaborating "real-typical" categories, abstracted from experience, is suitable for our study (Weber, 1949).

We explore the innovation, industrial and regional policy implications of the arts through exemplary case studies of the Ashland, Oregon Shakespeare Festival, the Manhattan SoHo Arts District, and the Royal College of Art (RCA) in London. The Ashland Shakespeare Festival is a model of university-region co-development in the arts. New York's SoHo is an instance of a bottom-up artists' initiative assisted by a citizens' neighborhood preservation movement and governmental regulation. The RCA is an exemplary arts research and educational institution whose focus on knowledge exchange, public and community engagement, and local growth regeneration suggests untapped potential for the role of arts and creativity in innovation and growth.

\section{The arts polity}

One may ask if cultural and commercial values in arts are irreconcilable. Nevertheless, it is undeniable that arts activities require a material base to exist, whether that is provided by artists' non-artistic income, philanthropic, and government sponsorship or sales. Thus, the noted composer Philip Glass's plumbing skills gave him the income to compose before he could attract commissions. The link between the cultural element and commerce is inevitable, yet, most importantly, the cultural value remains, and may be magnified, when the arts produce an economic effect.

Managing the tension between culture and commerce is a persisting issue (Hesmondhalgh and Pratt, 2010). Some consider culture as a factor with ultimate economic benefit. Bourdieu (1986) argues that "cultural capital" exists in three states: first, the embodied state which refers to the creative genius originating in a person; second, the objectified state which refers to the cultural element in goods and services; and third, an institutionalized state closely connected to the concept of social capital and education. Others view the arts as a more immediate source of innovation in a wide range of goods and services (Potts and Cunningham, 2015). Most advocates of a positive relationship between growth in the arts and growth in the overall economy trace it back to the supply, demand, creation, and diffusion of knowledge in general, without specifying the comparative advantage of the arts in unleashing imagination. Moreover, growth in the arts is explained as a result of an increased level of wealth, an increase in human capital, advancements in information 
and communications technology (ICT), and globalization; with arts themselves assigned a subordinate role.

The arts have an internal politics as well as a relationship to the larger society. O'Connor and $\mathrm{Gu}$ (2006) and O'Connor (2007) criticize the reduction of arts to a knowledge source that serves other industries. Together with Banks and O'Connor (2009), he further argues that "an understanding of both the cultural and the economic moments" (p. 367) is needed to explain the distinctive ways of value creation in the arts sector which, through their social impact, have an impact on the wider economy. In addition, the value assigned to the arts varies in a "cultural asymmetry" (Abbing, 2002, p. 67). Moreover, the degree of belief in a cultural value for the arts also seems to determine what is art and what is not (Abbing, 2002). Correspondingly, Abbing (2002) notes high uncertainty with respect to valuation. Valuation is a struggle among artists, collectors, museums, and galleries in various shifting alliances. There is an investment dilemma, similar to the one in science and technology, between balancing short-term stimulation of art consumption and the production of cultural value as a longterm investment (García, 2004). The degree of belief in a cultural value for the arts also seems to determine what is art and what is not, an issue brought to a head in the response to Duchamp's "readymades"-manufactured objects labeled for gallery exhibition.

Kebir and Crevoisier (2008) consider arts as a resource for a production system. Simonton (2014, p. 29) describes the process of value creation in arts as the actualization of creative genius into "artistic products." These creative products and, in the case of performance art, creative services, have an economic value in the direct sense as they are exchanged for money. However, the notion of a cultural value that goes beyond the economic one has been prominent in recent art-value discussions, where the notion of an industrial policy for the arts would be so beyond the pale as not to be taken seriously. Casson (2006), with his definition of culture, considers ways to express values and beliefs as one cultural component, comprising symbolic as well as artistic elements. According to Casson (2006), a culture is usually shared in a group, which corresponds with the importance of consensus in the context of the arts mentioned by Simonton (2014).

Art and cultural goods and services play an increasingly significant role in the US economy, accounting for $\$ 877.8$ billion or $4.5 \%$ of GDP, and the employment of 5 million people in 2017 (National Endowment, 2020). Indeed, arts and culture constitute a sector almost five times more important than agriculture.

The arts form a significant part of the UK's economy, with a $£ 90$ billion net contribution to the GDP and one out of 11 jobs belonging to this industry that are less likely to be lost to automation (Kampfner, 2016). Nevertheless, artsrelated industries have only relatively recently gained higher attention for their economic impact. The UK Creative Industry Federation (CIF) Manifesto argues that the creative industries are the fastest growing part of the country's economy, contributing £87bn in GVA. It returns four times the GVA of the automotive industry, six times as much as life sciences and nearly 10 times that of aerospace. Between 2011 and 2015, it created three times more jobs than the economy as a whole. The UK is the third-largest exporter of cultural goods and services in the world - just behind China and the US. (CIF, 2017)

The Manifesto further notes that "Over the past 5 years the sector has grown by $34 \%$ making it the fastest growing part of the UK's economy and the gross valued added of the sector could be $£ 120$ billion by 2022." (CIF, 2017)

The Cox (2005) Review on creativity in business, commissioned in 2006, highlighted the role of design as a link between creativity and innovation. A parallel study of 2005 by the Department of Trade and Industry (DTI, 2005) provided evidence of the impact of creativity on business performance and productivity. Both reports strongly argue that design and creativity are drivers for innovation, productivity and performance.

These conclusions are reinforced by a multi-year community assessment and planning effort, articulating long-, medium-, and short-term objectives, in Austin, Texas. This involved artists, arts organizations, neighborhoods, and government authorities with arts responsibilities. Building on an internationally recognized cluster of live music performances and a growing technology economy, the exercise highlighted the problem of siloed arts disciplines. The fact that each went its own way and competed for the same resources created difficulties in developing a common strategy. The need for a unifying cross-disciplinary framework as an underpinning of arts development emerged as a project conclusion (Cultural Arts Division, 2009).

\section{The PAVAM thesis}

Our premise is that the arts are essential to innovation and entrepreneurship as well as to culture and spiritual fulfillment. STEM originated in the 1990 s as a rubric in an educational program to encourage Hispanic youth to take up science. Adopted by the US National Science Foundation's educational bureaucracy, it focused attention on science education as an underpinning of research. Blackley and Howell (2015) narrate the story of the take-up of STEM, starting in the late 1990s. In the context of globalization and economic downturns, the term, combining four scientific fields, was quickly accepted as a one-size-fits-all solution to gain competitive advantage in the international environment. However, Blackley et al. also emphasize limits to a STEM-focused innovation strategy in preventing economic downturns even if, as a study from Australia reports, it is the 
underpinning for " $75 \%$ of the fastest growing occupations" (Gough, 2015). Yet, STEM itself does not automatically imply innovation and is not the only area in which innovation originates.

The narrow focus on STEM, Sousa and Pilecki (2013) argued, would even inhibit the learning of STEM skills. Looking for a more natural way to teach STEM, they merged the arts into STEM, creating STEAM (science, technology, engineering, arts, and mathematics). It is one of their major arguments that arts are necessary to build cognitive skills like creativity or problem solving, which are essential for long-term learning. Piro (2010) argues in favor of a balanced approach which empowers both, science and the arts. Sousa and Pilecki (2013, p. 44) equally mention the "convergent and divergent thinking" as a STEAM benefit and consider creativity as a means to overcome barriers of thought. These aspects underline the potential power of synergies which can be achieved via interdisciplinary linkages.

To connect the core disciplines in the arts back to the economy, we propose PAVAM (performing arts, visual arts, and music) in apposition to STEM as a complementary set of arts disciplines underlying the creative economy (Figure 1). A narrow focus on core subjects like math and English, taken in response to the 2008 US No Child Left Behind Act and the follow-up Common Core Standards (CSS) Act, resulted in sharp cuts to arts education, with the exception of music. The loss of creativity due to lack of exposure to the arts is expected to have a deleterious impact on the development in children of a broad variety of motor, language, and social skills that will negatively affect the sciences as well as the arts. The up and down, challenge and response to arts education funding is illustrated in the timeline of program rise, demise and re-rise of California's arts education programming (California Alliance, 2020). Imbalance has been traced back to the US response to the 1957 Soviet Sputnik success, which was widely perceived as ultimately due to educational flaws (Tamer, 2009).

PAVAM transcends the dichotomy of art as purpose in itself and art for profit. However, the conflicting ends make it difficult to transform cultural value into commercial value - a missing link between $R \& D$ in arts and the return

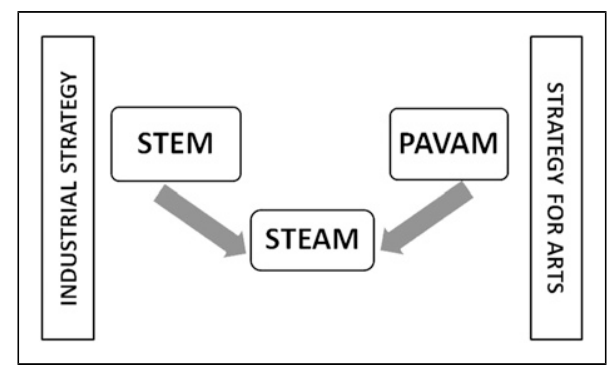

Figure I. Links between STEM, PAVAM, and STEAM. on investment (Abbing, 2002). Kebir and Crevoisier (2008) consider the arts as a fundamental resource for a production system, exemplified by the transformation of the watch from a mechanical to an aesthetic object.

PAVAM avoids some of the confusions engendered by the term "creative industry," a rubric that covers software fields separate from as well as those linked to the arts. While it has proved useful for the arts to tag on to software to gain more attention and for software to associate with the arts to gain copyright protection, a relatively small proportion of creative industry software is connected to the arts in a "fused technology" akin to the synthesis of mechanical and electronic engineering to create mechatronics, or of mechanical engineering and the visual arts to create design thinking. Below, a typology of the sources of the economic impact of the arts is inferred from comparative case studies, demonstrating the variety of ways in which the arts contribute to the economy.

\section{Assessing the arts' economic impact: A comparative case study analysis}

Deploying the proposed research methodology, we will use the following case studies in order to derive a typology of the art and design capabilities as instrumental enablers for innovation, economic development, and growth.

\section{Arts entrepreneurship: an under-rated phenomenon}

A natural resource-based economy with a superseded railhead found a new economic base through the creation of a PAVAM cluster, representing the industrial sphere in this local Triple Helix. A civil society platform, undergirding the Triple Helix, encouraged citizen mobilization to support a modest academic initiative. Moreover, federal government support of the local effort, through supplementary funding of its expansion, increased its impact. Today, Ashland, Oregon sees itself as a Humanities Town, hosting theater festivals spun off from the original festival as well as attracting visual arts and crafts activities. A hospitality industry grew alongside this development to host visitors and the cultural ambiance attracted retirees from the San Francisco Bay Area.

The festival had a long path to economic impact, building on its local academic and cultural significance. The Oregon Shakespeare Festival (OSF), founded in 1935 and with roots back to the 1890 s, is one of the oldest cultural festivals in the USA (Engle et al., 1995). In 2014, a ticket sale of 400,000 was reported, with 125,000 people visiting the city, generating $\$ 261$ million (Hale, 2016). The OSF showed exceptional robustness in the 2008 financial crisis. Despite a budget cut, higher ticket sales were registered (Roberts, 2010). The way in which a development pathway was achieved, with critical obstacles overcome, provides 
essential clues as to how to strengthen the economic impact of the arts.

The contemporary cluster was built on the base of an existing local artistic cluster in Ashland, which comprised literature, bibliography studies and performance arts. In the late 19th century, an auditorium was built as a local outpost of the National Chautauqua movement, a combination of religious revival and cultural event, setting the first structural element in motion for the subsequent Festival. It was first enlarged to accommodate more people and then removed in the 1920 s crisis that closed the local Chautauqua program. However, the theater was then rebuilt as an open-air theater on the foundations of the old structure at the inception of the Festival (Engle et al., 1995).

Angus Bowmer, a neophyte theater academic, entrepreneured the Festival as a means to fulfill his academic remit of teaching normal school students to mount plays, a key part of their future job as secondary school drama teachers. A member of a local booster club, Bowmer recruited townspeople to help put on a Shakespeare play as part of their July 4th celebration and then extended its success into a regular summer festival. As a professor at Southern Oregon University and an alumnus of Stanford, Bowmer's academic connections benefited the festival. A Stanford English professor with whom he studied, Dr Margery Bailey, used the Festival as a field site for her students, adapting the geological training model. In addition, she contributed expertise on Elizabethan theater and co-founded an academic center at the local university. Stanford academics still provide lectures explicating OSF performances.

Closed during the Second World War, the theater reopened directly thereafter, propelled by pre-war national recognition. In 1965 , it was working to capacity. The season, which had been restricted to the warmer months, was extended to accommodate more visitors. In 1966, musicals and operas were added, generating higher income. A university report showed the positive local economic impact of the Festival and helped attract a grant from the US Economic Development Administration. Along with local fund raising, this made possible construction of an indoor theater. The mounting number of visitors was closely linked to an improvement in performance quality, resulting from talent attracted by the cluster (Engle et al., 1995). The university's theater school attained national status through its symbiosis with the Festival, with Festival personnel serving as teachers and students working as Festival interns.

The Hay Festival in Wales mirrors some of Ashland's experience. Similar to the Oregon experience, the extension of the time in which the event could take place has been a critical factor in expanding its scope. Initially lasting a weekend, it is now held over 10 days every year. Equally, a broader range and higher number of events during the
Festival have combined with larger event spaces to increase its impact on the local economy. Another entrepreneur, Peter Florence, has driven this success story. He managed to scale up financing from a local level to a budget with contributors from different industries and associations (European Design Commission, 2011).

\section{A Silicon Valley of the arts?}

An area that successively renews itself as the site of a multiplicity of arts activities qualifies as a "Silicon Valley" of the arts. Lower Manhattan's West Side Greenwich Village, above the financial district and below the flower and garment districts, has been a long-term site for artistic activity in the visual and theater arts and literature (Ware, 1935). The Village became an attractive residential quarter for non-artists who were attracted to the arts, and gradually less affordable to artists given the expansion of demand. By the 1960s visual artists, working on a large scale and seeking bigger spaces, discovered a declining manufacturing district below the Village and began to rent lofts, former industrial workshops, using them as joint living and working spaces. This took place sub-rosa as the area was zoned industrial. The Foundation for the Community of Artists, an organization of artists and social scientists, foreseeing that Village gentrification could replicate, gained municipal assent for a certification process, with artists vetting artists, limiting the area to working artists (Etzkowitz and Raiken, 1980).

Nevertheless, the renovation of former factories by artists with construction skills set in motion a gentrification dynamic that the real estate industry built on. Certification strictures only moderated gentrification, which accelerated when galleries opened on the first floors of the loft buildings, attracting collectors and tourists to the area, and then bars, restaurants, and other support services. An expansion from visual arts to other arts activities, like experimental theaters, needing large, open spaces also occurred. Real estate investors took note and the area soon received the distinctive name SoHo, for "South of Houston Street" and a play on the bohemian London neighborhood of the same name. Branches of upscale department stores, boutiques, and restaurants now denote the area while many artists have moved on to new frontiers, like DUMBO (Down Under Manhattan Bridge), Brooklyn, New Jersey, and further afield, while a significant number of artists and galleries who purchased their spaces in the early days, when prices were low, persist.

The succession of arts activities, where new formats are created as old ones are superseded, identify Lower Manhattan as an Innovative Region. The Kitchen in New York is an institution which arose out of the SoHo arts movement in the 1970s, showing all the mentioned types of linkages. Its initial focus on video and performance escalated into an 
interdisciplinary, experimental arts space and the initial group was institutionalized, building an organization with international prominence. Above all, linkages to surrounding institutions have been established which is illustrated by the educational programs the organization does in cooperation with high schools (The Kitchen, 2018). The Kitchen may be viewed as an arts R\&D institute, inventing new forms of arts modalities, and disseminating them through regular performance tours of university campuses across the country.

\section{Leading the STEAM agenda}

Established in 1837 as the Government School of Design, the Royal College of Art in London offers an example of STEAM in action, "placing critical value on the catalyzing power of the creative arts...". (RCA Annual Report, 20162017). The RCA is the only entirely postgraduate art and design university in the UK, educating some 2300 graduate students from over 70 countries annually. Since 2015 the RCA has been recognized as the world's top university in art and design (QS World University Rankings).

Despite its name, the RCA is home to four schools (Architecture, Arts and Humanities, Communication, and Design), offering a diverse and broad range of art and design disciplines which span city design, environmental architecture, intelligent mobility, innovation design engineering, design products, service design, fashion, information experience design, digital direction, animation, and a comprehensive range of visual arts disciplines including painting, graphics, glass and ceramics, jewelry, and photography.

The RCA's industry partnerships extend far beyond the traditional creative industry sector and it attracts businesses from telecommunications, technology, healthcare, banking, finance, automotive, manufacturing, and consumer products companies. In addition to traditional forms of collaboration (e.g., contract research, collaborative research, and consultancy), the RCA is actively engaged with industry via innovative studio projects. These are short-term activities which are built into Master's programs and offer students practical insights into real-world challenges. Studio projects are structured as two-way partnerships, bringing together industry expertise and the RCA's creativity and design capabilities. Businesses value the projects as a way to explore future speculative scenarios, as a safe place to innovate and an opportunity to develop a disruptive culture.

The RCA is also home to InnovationRCA, the UK's most successful incubator, with 'the highest number of student spin-outs with university ownership in recent years in the UK' (HEFCE, 2015). In the past 10 years, InnovationRCA has launched 50 start-ups, generated $£ 58$ million in turnover, raised $£ 39$ million in investor funds and created over 600 jobs in the UK only. Despite being spin-outs from the art and design alma mater, start-ups offer technologies for sustainable energy, healthcare and wellbeing, new materials, $\mathrm{AR} / \mathrm{VR}$, and robotics. The spin-outs export to more than 80 countries (RCA, 2018).

One of the enabling factors is the RCA's location at the heart of Albertopolis, an area around London's Exhibition Road, which is named after the Great Exhibition of 1851. Prince Albert, husband of Queen Victoria, championed the first international exhibition to celebrate advances of the first Industrial Revolution. The Great Exhibition of the Works of Industry of All Nations (sometimes referred as the Crystal Palace Exhibition) was organized by the Royal Society for the Encouragement of Arts, Manufactures and Commerce in order to expose British design to foreign competition (V\&A, 2018). It received an unprecedented international resonance and was attended by six million people. The profits from the event were used to create the first cultural and educational quarter to promote art and science and to set up trusts for scholarships and grants for industrial research.

Today, Albertopolis is home to some of the world's leading art, science, and technology institutions, including the Victoria and Albert Museum (V\&A), the Science Museum, the Natural History Museum, Imperial College London, the Royal College of Art, the Royal Albert Hall, the Royal College of Music, and the Royal Geographical Society. Such co-location has a positive effect on creating local and regional partnerships, collaboration between institutions, joint degree programs, and research.

\section{Discussion: PAVAM in action}

Arts developed to express deep human needs for creative expression have spillover economic effects that are captured through the creation of organizations and roles (e.g., galleries, theaters, and impresarios) to bring together producers and consumers of the arts. Art creates economic value directly through its own production and dissemination. It also bestows its aura on and adds value to other activities (Benjamin, 1959). Beyond direct links through commercialization, in inspiring other disciplines the arts have an indirect economic impact (Laundry, 2012). Artists educate societies as they challenge rigidified structures, breaking rules when they question societal boundaries. Thus, the arts "represent progress, challenge and change" by bringing forth new perspectives in times of crisis (Baniotopoulo, 2001). The creative destruction of norms by the arts, in challenging the status quo, facilitates a new future-led orientation, especially useful in addressing crises.

The dichotomy of art in itself and art for profit mirrors the demand-pull versus the science-push innovation with science replaced by arts (Abbing, 2002). The uses of the arts determine their value; this is why, in the following, a framework is employed that takes into account both 
commercial and cultural use (Figure 2). It distinguishes between two major user groups, the civil society and the economy. Although the latter technically consists of society's subjects, economically acting users may have objectives that lead to a use of art that is different from the cultural use by a subject that acts as a citizen. Thus, the distinction facilitates the explanation of the value of the arts. The recipients and creators of cultural value are citizens: the relationship of artists to civil society is exemplified in the transformation of Ashland from a natural resource-based economy to an arts-based town (Etzkowitz, 2015), as described above.

Among others, Markusen (2006) discovered local creative clusters, which unlock artistic creativity and regional growth. Specifically, she refers to the spatial density of artists as a condition for a higher economic output. Whereas art clusters are linked to cultural consumption, a variety of industries use it as a tool for production or marketing. This is often reflected in collaborations between artists and commercial organizations. There is a small, but notable difference between the arts as a complementary (and thus equal) partner and the arts as a means to create commercial value directly. Thus, practical application of the arts ranges from cultural use at one end to commercial use at the other end; for example, in art industries: films, computer games or fashion design. Fusion with technology is vital for many of these. The categories of cultural and commercial uses of art are further summarized in Figure 3 and Table 1.

It is remarkable that the arts are increasingly seen as an instrument of economic recovery. This was the case at the Oregon Shakespeare Festival as well as at the Guggenheim Museum in Bilbao. Baniotopoulou (2001) explains that modern arts "represent progress, challenge and change," which allows for new perspectives in times of crisis. The creative destruction of norms and rules by the arts may therefore be essential in recessions or depressions because they challenge the status quo and provide a new future-led orientation. Christo and Jeanne-Claude's international projects, engaging with citizens and local authorities to obtain permission for such artistic projects as "Wrapping the Reichstag" exemplify the interplay between artistic

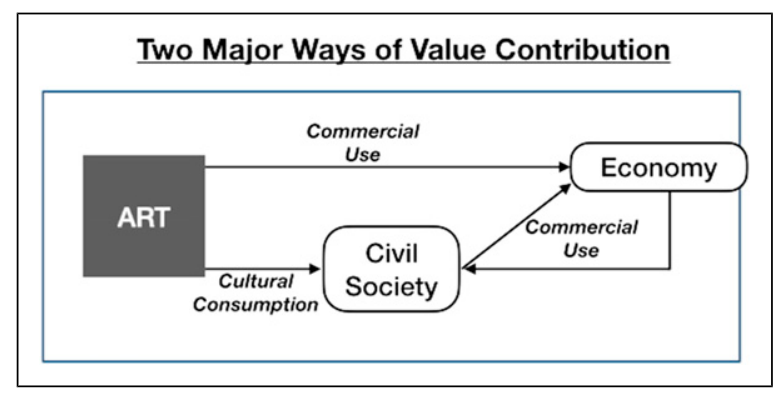

Figure 2. Commercial versus cultural use of the arts. creativity and civic culture, and the project creates its own funding base through sale of artifacts. ${ }^{2}$ A mixture of eventled and infrastructure-led policies should be encouraged, so that regeneration is driven by both short-term and long-term initiatives to balance cultural production and consumption (García, 2004). It is essential to promote networking between creative organizations and design policies to leverage regional creativity and build ties to national and international levels.

\section{Three effectuation pathways}

As discussed earlier, based on the cultural and commercial use of art, we can distinguish three effectuation pathways for arts application: art as creativity, art as knowledge production and art as economic input (Table 1). Each of these pathways generates a distinct value derived from art, that is, cultural, social, or commercial, which, in turn, has a certain cultural, social, economic or commercial effect, as demonstrated through the case studies. A time-consuming education makes it particularly important that universities support their students in converting their artistic efforts into an economic benefit. Industry, in turn, could decrease its risk of uncertainty when entering into cooperation with universities by working with potential employees in projects, internships or other educational models. The RCA's educational approach and partnership with industry offer a valuable combination of academic and practical knowledge which helps to make its graduates work-ready. The RCA has a high employment rate for its graduates, with over $90 \%$ being in an appropriate level of employment within 12 months of graduation (HESA Graduate Outcome Survey, 2017-2018). Moreover, $40 \%$ of its graduates choose to establish their own businesses (RCA Annual Report, 20182019, p. 112).

University-industry collaboration based on PAVAM disciplines often requires different types of partnership than for STEM. Taking the example of the RCA, such partnerships are increasingly based on knowledge exchange models that focus on the co-creation of new knowledge rather than using a linear knowledge transfer approach (which has been traditionally applicable to STEM disciplines). A UK study conducted by Kingston University in partnership with University Alliance provides a taxonomy of university-industry partnerships in the creative industries and attempts to evaluate their effectiveness via a Cultural Impact Compass. The Cultural Impact Compass offers a framework to evaluate university-industry partnership and its impact on the creative economy. The key axes in the evaluation of collaborative projects are: fostering creativity, wealth creation, regeneration and creating quality places, social and cultural cohesion and infrastructure for learning (Kingston University, 2017). 


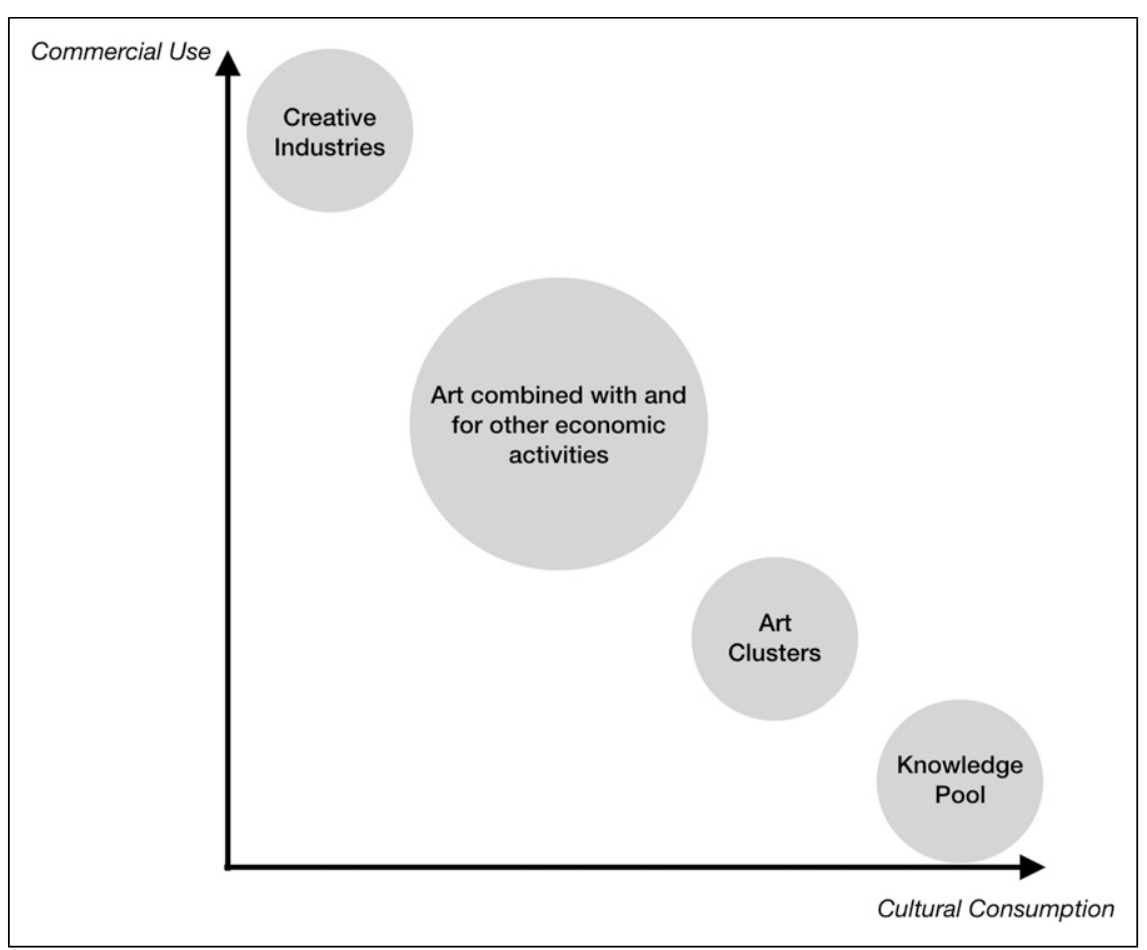

Figure 3. PAVAM activities between cultural and commercial consumption.

Table I. The economic value of the arts.

\begin{tabular}{|c|c|c|c|c|}
\hline & Value of arts & Effect & Examples & Case studies \\
\hline Arts as creativity & Cultural & $\begin{array}{l}\text { Creative clusters } \\
\text { Social adhesion } \\
\text { Spillover effect }\end{array}$ & $\begin{array}{l}\text { Art galleries } \\
\text { Art festivals }\end{array}$ & $\begin{array}{l}\text { Oregon Shakespeare Festival } \\
\text { (OSF) }\end{array}$ \\
\hline $\begin{array}{l}\text { Arts as knowledge } \\
\text { production }\end{array}$ & Cultural and social & $\begin{array}{l}\text { New knowledge } \\
\text { New research } \\
\text { New skills } \\
\text { Employment }\end{array}$ & $\begin{array}{l}\text { Art schools } \\
\text { Experimental art and design } \\
\text { institutions }\end{array}$ & $\begin{array}{l}\text { The Royal College of Art (RCA) } \\
\text { The Kitchen }\end{array}$ \\
\hline $\begin{array}{l}\text { Arts as economic } \\
\text { input }\end{array}$ & Commercial & $\begin{array}{l}\text { Art- and design-led } \\
\text { innovation }\end{array}$ & $\begin{array}{l}\text { Creative industries, digital and } \\
\text { technology businesses }\end{array}$ & Pixar \\
\hline
\end{tabular}

The university plays an increasingly central role as a cross-disciplinary platform for both PAVAM and STEM, thus creating and enhancing a fusion between arts, science, technology and innovation. An example of such a crossdisciplinary springboard is a collaboration between Stanford visual arts and mechanical engineering professors, originated a half century ago. A joint project-based, industry-linked educational venture persists to this day, spinning off a multiplicity of design firms like IDEO, research organizations such as the Center for Design Research, and teaching units like the Hasso Plattner D-School, with its corollaries in Potsdam and Capetown. Furthermore, an arts industrial element becomes visible in "creative industries" (Potts, 2009; Potts and Cunningham, 2015) where arts are commercialized. This commercialization can be considered a link between the educational and civic spheres, with the arts primarily serving cultural consumption while contributing to economic productivity.

Art clusters use cultural attraction to create economic benefits through cognate business activities such as restaurants and other hospitality industries. Two major types of use may be identified: first, using arts as a tool or complement without substantially altering their original characteristics and, second, using them to serve business so that they are designed or altered for a business purpose. Whereas the first often includes cultural use (such as art collections within commercial companies), the second may be seen as a fusion between cultural and commercial use. In contrast, 
creative industries constitute the other end of the scale with their direct commercial use of arts.

Pixar, now part of Disney, exemplifies an industry-led strategy in which various creative activities are concerted to create a commercial outcome. Arts in the motion picture studio are subordinated to business strategy, although financial success provides occasional opportunities for breakthrough in their own right. At Pixar, collective creativity plays a dominant role and is understood as a community which is independent to some degree when it comes to the creative implementation of higher-level decisions. The company comprises a strong talent for that purpose. One frequent pattern in creative industry companies is the fusion between technology and arts; this can also be found at Pixar, where design, comic art, performance art, and technology merge into a movie (Catmull, 2008).

Art institutions, often owned by government, can be a springboard for local clusters, top-down. A study of arts in Tucson (Arizona) showed that government funding for art institutions led to the establishment of an arts cluster that attracted visitors and benefited other local industries. More importantly, there was a considerable employment effect, generating incomes and thus stimulating the local economy. Moreover, revenues coming from the overall economic impact of art institutions have exceeded government spending, thus generating a return on investment (Pavlakovich-Kochi and Charney, 2000).

\section{Enhancing arts innovation: policy measures}

A new generation of policy making acknowledges creative activity as an important industry in its own right. Chang et al. (2013) suggest the installation of planning offices and additional structures to ensure continued cooperation between public and private institutions in the creative sector. They propose a division of the industrial policy landscape into dimensions for creative industries, with large corporations and small and medium-sized enterprises (SMEs) forming one dimension and an educational component an additional dimension. The US Government's National Institute of Standards and Technology (NIST) helps businesses establish partnerships with other businesses for both effective supply-chain management and the expansion of products and services. However, the focus is still on manufacturers. Taking into account the high value potential resulting from the arts, similar supporting services should be offered for creative industries.

The UK's Industrial Strategy, "Building a Britain fit for the future" (HM Government, 2017), identifies London as a world-leading hub for creative industries alongside financial services and tech. The Industrial Strategy White Paper makes a link between the creative industries and STEM as a foundation for new skills development. We suggest that it is also important to focus on PAVAM disciplines as a foundation for creative industries as well as developing a cross-disciplinary research and education focus. Despite the potential of an alternative interdisciplinary approach, it presents challenges with respect to performance measures. Unlike the case of the STEM disciplines, art policy studies seem to be limited to status quo analyses which may reflect the directly connected value production by creative industries but fail to design measures to improve their impact in the future (see Chang et al., 2013; Comunian, 2011).

To capture a diverse range of university-industry collaboration, the UK Government has developed the Knowledge Exchange Framework (KEF), which is led by UK Research \& Innovation, the national funding agency investing in science and research. The KEF focuses on the efficiency and effectiveness of knowledge exchange, developing a balanced and transparent approach for universities across different disciplines.

The UK Government has committed to making transformative investments in technologies and creative clusters throughout the country via its Industrial Strategy Challenge Fund (HM Government, 2017). For example, in 2018 the government launched an $£ 80$ million Creative Industries Clusters Programme competition, led by the Arts and Humanities Research Council (AHRC), with the aim of establishing eight creative Research and Development (R\&D) Partnerships between universities and businesses to strengthen the UK's position in the creative industries. In a further attempt to understand the impact of the creative industries on the UK's economy, a national Creative Industries Policy and Evidence Centre was established to collect evidence of that impact (Bazalgette, 2017).

Haseman and Jaaniste (2008) see the arts as a key element of a practice-led approach to innovation, redressing what they view as an imbalance in science- and technologyled innovation policies. They advocate for the arts as social innovation and focus on the role of the arts in educating a new breed of innovative workforce. Klamer (2012), extrapolating from best-practice crafts industries, calls for a combined education and work experience format to be built into multidisciplinary degree programs - an approach currently practiced in Japan and other Asian countries and in "co-op" degree programs in the USA. Self-employment and small businesses are crucial links in the arts innovation value chain, so entrepreneurship education is needed at all levels.

Based on the comparative analysis of case studies and literature review, we propose the following recommendations, which utilize the value of PAVAM disciplines and promote interdisciplinary innovation and economic and social growth. Universities need to develop a new set of skills and capabilities to produce a new breed of crossdisciplinary boundary spanners. Governments need to adapt more agile policies recognizing the role of arts and design in national competitiveness. Industry needs to connect with 
Table 2. PAVAM policy recommendations.

\begin{tabular}{|c|c|c|c|}
\hline & Government & University & Industry \\
\hline Strategy & $\begin{array}{l}\text { Encourage HEI partnerships across } \\
\text { disciplines as an effective tool to } \\
\text { leverage public investment and } \\
\text { increase spillover effects }\end{array}$ & $\begin{array}{l}\text { Formulate strong knowledge } \\
\text { exchange strategies to ensure two- } \\
\text { way knowledge flow }\end{array}$ & $\begin{array}{l}\text { Adopt open innovation and } \\
\text { Triple Helix strategies }\end{array}$ \\
\hline Education & $\begin{array}{l}\text { Stimulate interdisciplinary education } \\
\text { across all levels of education, from } \\
\text { schools to HEls }\end{array}$ & $\begin{array}{l}\text { Develop and add creative and design } \\
\text { modules within STEM degrees to } \\
\text { increase critical thinking } \\
\text { capabilities and skills of graduates } \\
\text { Support the development of } \\
\text { technology and science modules } \\
\text { within PAVAM degrees to facilitate } \\
\text { interdisciplinary projects and } \\
\text { possibilities }\end{array}$ & $\begin{array}{l}\text { Contribute to education } \\
\text { curricula by bringing real- } \\
\text { world case studies and } \\
\text { expertise }\end{array}$ \\
\hline Research & $\begin{array}{l}\text { Facilitate further research into the } \\
\text { role of art and design in disruptive } \\
\text { innovation }\end{array}$ & $\begin{array}{l}\text { Developing professional doctorate } \\
\text { and research programs }\end{array}$ & $\begin{array}{l}\text { Engage in collaborative and } \\
\text { contract research with } \\
\text { universities }\end{array}$ \\
\hline Partnerships & $\begin{array}{l}\text { Facilitate university-industry } \\
\text { collaboration in arts and design } \\
\text { disciplines to achieve a multiplier } \\
\text { effect }\end{array}$ & $\begin{array}{l}\text { Establish cross-departmental } \\
\text { collaboration and idea generation } \\
\text { workshops } \\
\text { Involve industry professionals in } \\
\text { education processes }\end{array}$ & $\begin{array}{l}\text { Extend conventional STEM } \\
\text { partnerships to arts and design } \\
\text { schools to stimulate innovation } \\
\text { culture in business }\end{array}$ \\
\hline Finance & $\begin{array}{l}\text { Facilitate interdisciplinary and } \\
\text { transdisciplinary research through } \\
\text { relevant grants and funding } \\
\text { schemes }\end{array}$ & $\begin{array}{l}\text { Offer sponsorship to talented } \\
\text { individuals to encourage diversity }\end{array}$ & $\begin{array}{l}\text { Support talented students, } \\
\text { graduates and joint research } \\
\text { programs }\end{array}$ \\
\hline Outreach & $\begin{array}{l}\text { Promote and support PAVAM } \\
\text { education and research as a } \\
\text { counterpart to STEM and the role } \\
\text { of creative industries as part of } \\
\text { national industrial strategies }\end{array}$ & $\begin{array}{l}\text { Promote the enabling role of PAVAM } \\
\text { and design disciplines in innovation, } \\
\text { growth and productivity }\end{array}$ & $\begin{array}{l}\text { Promote the role of arts and } \\
\text { design in innovation and } \\
\text { economic recovery }\end{array}$ \\
\hline $\begin{array}{l}\text { Innovation, } \\
\text { entrepreneurship, } \\
\text { and skills }\end{array}$ & $\begin{array}{l}\text { Supporting cross-disciplinary } \\
\text { clusters and innovation } \\
\text { ecosystems to facilitate new } \\
\text { discoveries and unorthodox } \\
\text { approaches to innovation } \\
\text { Develop IPR frameworks to ensure } \\
\text { adequate protection of non-patent } \\
\text { IP (e.g., design rights, copyright) } \\
\text { Support arts accelerators with } \\
\text { mentors and investment funds }\end{array}$ & $\begin{array}{l}\text { Support student and graduate } \\
\text { placements, internships, and } \\
\text { recruitment }\end{array}$ & $\begin{array}{l}\text { Utilize art schools' expertise in } \\
\text { creativity, critical thinking and } \\
\text { design to reignite business } \\
\text { culture and a decision-making } \\
\text { process }\end{array}$ \\
\hline
\end{tabular}

universities to exchange knowledge and apply arts and design to develop new products, services and experiences. More practical recommendations are summarized in Table 2.

\section{Conclusion: Words matter}

The knowledge economy requires a wider focus as knowledge exchange between disciplines is key to innovation (Redshaw, 2004). Thus, we have posited a set of arts disciplines, PAVAM, as a counterpart to STEM, holding that support for these disciplines is justified on the dual criteria of cultural and economic advancement. We have presented a typology of the economic value of the arts and have assessed their economic impact through case studies to consider their role in innovation. Interaction among institutional spheres enables the transformation from cultural to commercial value, expanding projects with otherwise modest impact into projects that have significant effects, both cultural and economic.

In this article, we focus on the role of the arts as an enabling force in their own right for technological advancement and economic growth. We hold that breakthrough innovation fundamentally comes from interdisciplinary and cross-disciplinary collaborations (Liu et al., 2021). There are multiple examples in history of 
breakthrough discoveries originating from great inventors whose work spans multiple disciplines and extends into art and design (e.g., Leonardo da Vinci, inventor and photography pioneer Henry Fox Talbot, and elocution teacher and telephony inventor Alexander Graham Bell). We have also identified novel ventures by arts innovators of modest backgrounds and limited access to resources, like Ashland's drama entrepreneur, Angus Bowmer, and the political artists and sociologists involved in the germination of New York's SoHo arts/industrial district. Policy initiatives may usefully adapt and model themselves on bottom-up initiatives like the OSF, with significant spillover effects into local academia and the regional economy.

A "Medici effect" of creative and commercial efflorescence can best be achieved if we bring together crossdisciplinary expertise and a diverse range of players including industry, SMEs, the public sector, charities and governments in an open dialogue (Carayannis and Campbell, 2014), as individuals as well as organizational entities. It is through such interaction, led by respected conveners in neutral venues, existing or newly created, that the venture capital model or arts action organizations like the Foundation for the Community of Artists are birthed.

We suggest the following specific development measures, some of which already exist in nucleo: (1) grants for cross-disciplinary collaborations among the arts; (2) local libraries of construction tools for arts squatters; (3) arts accelerators with mentors and investment funds, both as independent entities or associated with art colleges, museums, symphony orchestras and other established arts institutions; (4) a Knowledge Transfer Partnership (KTP) scheme adapted to PAVAM, including a two-way flow into and out of academia; and (4) adaptation of the New York SoHo "Kitchen" interdisciplinary arts R\&D model for transfer as a PAVAM analogue to the Franklin, Turing, and Crick Institutes.

In his reply to the poet Samuel Coleridge, who held that "natural philosopher" was too broad a term to apply to those who engaged in practical activities like digging in fossil pits and experimenting with electricity, polymath William Whewell proposed that, by analogy with "artist," we may form "scientist," thus inventing the term (Snyder, 2011:3). Although widespread take-up of the neologism took some decades, it eventually provided a secure linguistic base for legitimating an emerging profession. Echoing this exchange, which took place at the third meeting of the British Association for the Advancement of Science in 1833, we essay to bridge another legitimation gap by posing PAVAM in apposition to STEM. We trust that PAVAM may provide advocates with as useful a platform to encourage support for arts education as STEM does for the sciences.

\section{Declaration of conflicting interests}

The author(s) declared no potential conflicts of interest with respect to the research, authorship, and/or publication of this article.

\section{Funding}

The author(s) received no financial support for the research, authorship, and/or publication of this article.

\section{ORCID iD}

Tatiana Schofield (i) https://orcid.org/0000-0001-5543-5560

\section{Notes}

1. An early version of this paper was presented to the Bath University Industrial Policy Workshop, 19 April 2018.

2. http://christojeanneclaude.net/projects/wrapped-reichstag

\section{References}

Abbing H (2002) Why Are Artists Poor?: The Exceptional Economy of the Arts. Amsterdam: Amsterdam University Press.

Andreoni A and Chang H-J (2016) Industrial policy and the future of manufacturing. Economia e Politica Industriale: Journal of Industrial and Business Economics 43(4): 491-502.

Apple Inc (2018) Today at Apple. Available at: https://www.apple. com/today/ (accessed 08 June 2018).

Baniotopoulou E (2001) Art for Whose Sake? Modern Art Museums and their Role in Transforming Societies: The Case of Guggenheim Bilbao. Journal of Conservation and Museum Studies 7: 1-5.

Banks M and O'Connor J (2009) After the creative industries. International Journal of Cultural Policy 15(4): 365-373.

Barzotto M, Corradini C, Fai F, et al. (2019) Enhancing innovative capabilities in lagging regions: an extra-regional collaborative approach to RIS3. Cambridge Journal of Regions, Economy and Society 12(2): 213-232.

Bazalgette P (2017) Independent review of the creative industries. Available at: https://assets.publishing.service.gov.uk/ government/uploads/system/uploads/attachment_data/file/ 649980/Independent_Review_of_the_Creative_Industries. pdf (accessed 08 December 2018).

Becker HS (1974) Art as collective action. American Sociological Review 39(6): 767-776.

Benjamin W (1969/1935) Art in the Age of Mechanical Reproduction. New York: Shocken Books.

Blackley S and Howell J (2015) A STEM narrative: 15 years in the making. Australian Journal of Teacher Education, 40(7): 102-112. Doi: 10.14221/ajte.2015v40n7.8.

Bourdieu P (1986) The forms of capital. In: Richardson J (ed) Handbook of Theory and Research for the Sociology of Education. Westport, CT: Greenwood: 241-258. 
Boy GA (2013) From STEM to STEAM: Toward a human-centred education, creativity \& learning thinking. In: Proceedings of the 31st European conference on cognitive ergonomics.

Brewer K (2016) Art works: How Art in the Office Boosts Staff Productivity. The Guardian. Available at: https://www. theguardian.com/careers/2016/jan/21/art-works-how-art-inthe-office-boosts-staff-productivity (accessed 6 June 2018).

Bridgstock R (2013) Not a dirty word: Arts entrepreneurship and higher education. Arts and Humanities in Higher Education 12: $2-3$.

California Alliance (2020) Historical Context. Pasadena: California Alliance for Arts Education artsed411.org

Carayannis EG and Campbell DF (2014) Developed democracies versus emerging autocracies: arts, democracy, and innovation in Quadruple Helix innovation systems. Journal of Innovation and Entrepreneurship 3(1): 12. DOI: 10.1186/s13731-014-0012-2.

Casson M (2006) Culture and economic performance. Handbook of the Economics of Art and Culture 1: 359-397.

Catmull E (2008) How Pixar Fosters Collective Creativity. Boston, MA: Harvard Business School Publishing.

Caves RE (2000) Creative Industries: Contracts between Arts and Commerce. Cambridge (Massachusetts), London (UK): Harvard University Press.

Chang H-J, Andreoni A and Kuan ML (2013). International industrial policy experiences and the lessons for the UK. Future of Manufacturing Project 4: 76.

Clark JD (ed) (2003). Globalizing Civic Engagement: Civil Society and Transnational Action. Routledge.

Cogswell College (2018). Available at: https://cogswell.edu/ (accessed 27 August 2018).

Collingwood R (1925) Outlines of a Philosophy of Art. Thoemmes Press.

Comunian R (2011) Rethinking the creative city: The role of complexity, networks and interactions in the urban creative economy. Urban Studies 48(6): 1157-1179.

Comunian R, Faggian A and Li QC (2010) Unrewarded careers in the creative class: The strange case of bohemian graduates. Papers in Regional Science 89(2): 389-410.

Connor AM, Sangeeta K and Chris W (2015) From STEM to STEAM: Strategies for enhancing engineering \& technology education. International Journal of Engineering Pedagogy 5(2): 37-47.

Cox G (2005) Cox review of creativity in business: building on the UK's strengths', Executive Summary. Available at: http:// webarchive.nationalarchives.gov.uk/20130129110402/http:/ www.hm-treasury.gov.uk/d/Cox_review-foreword-definitionterms-exec-summary.pdf (accessed 08 December 2018).

Cultural Arts Division (2009) Create Austin: Cultural Master Plan. Austin: City of Austin: Economic Growth \& Redevelopment Services Office

Creative Industries Federation (CIF) (2017) A General election manifesto for the creative industries. Available at: https:// www.creativeindustriesfederation.com/news/general-electionmanifesto-creative-industries (accessed 08 December 2018).
Cunningham S (2004) The humanities, creative arts, and international innovation agendas. In: Kenway J, Bullen E and Robb S (eds) Innovation and Tradition. The Arts, Humanities and the Knowledge Economy. New York: Peter Lang, 113-124.

Cunningham S and Cutler T (2004) An innovation agenda for the creative industries: where is the R\&D? Culture and Policy 29(112): 174-185.

Cunningham S and Higgs P (2009) Measuring creative employment: Implications for innovation policy. Innovation: Management, Policy and Practice 11(2): 190-200.

De Blieck A (2013) San Diego 2013: The Scene. Available at: https://www.cbr.com/san-diego-2013-the-scene/(accessed 28 May 2018).

Deissinger T (1994) The evolution of the modern vocational training systems in England and Germany: A comparative view. Compare 24(1): 17-36.

Department of Trade and Industry (2005) DTI Economics paper No 15. Creativity, Design and Business Performance. Available at: http://www.ico-d.org/database/files/library/ economics_paper15.pdf (accessed 08 December 2018).

Design Commission (2011) Restarting Britain. Design Education and Growth. Policy Connect. Available at: https://www. policyconnect.org.uk/apdig/sites/site_apdig/files/report/284/ fieldreportdownload/design-commission-restarting-britaindesign-education-and-growth.pdf (accessed 08 December 2018).

Dougherty D and Dunne DD (2011) Organizing ecologies of complex innovation. Organization Science 22(5): 1214-1223.

Eisenstadt K 1989. Building theories from case study research. Academy of Management Review 14(4): 532-550.

Elliott L (2016) March of the makers remains a figment of Osborne's imagination. The Guardian January. Available at: https://www.theguardian.com/business/2016/jan/12/ march-of-the-makers-osbornes-economy-manufacturingoutput (accessed 09 June 2018).

Engle R, Londre FH and Watermeier DJ (1995) Shakespeare Companies and Festivals: An International Guide, Greenwood Publishing Group.

Etzkowitz H (2015) Making a humanities town: knowledgeinfused clusters, civic entrepreneurship and civil society in local innovation systems. Triple Helix 2(1): 1-22.

Etzkowitz H and Raiken L (1980) Artists Social Movements of the 1960s and 70s: From Protest to Institution Formation. Washington DC: ERIC

Etzkowitz H and Zhou C (2017)The Triple Helix: UniversityIndustry-Government Innovation and Entrepreneurship. 2nd edition. London: Routledge.

Etzkowitz H and Zhou C (2018) Innovation incommensurability and the science park. R\&D Management 48(1): 73-87.

European Commission (2011) European Arts Festivals. Strengthening cultural diversity. Brussels: Technical report, EU Commission. 
Foreign and Commonwealth Office and The Rt Hon George Osborne (2011) 2011 Budget: Britain Open for Business. Available at: https://www.gov.uk/government/news/2011budget-britain-open-for-business (accessed 20 June 2018).

Garcia B (2004) Cultural policy and urban regeneration in western European cities: Lessons from experience, prospects for the future. Local Economy 19(4): 312-326.

Ghanbari S (2014) STEAM: The wave of the future embedded in ideals of the past. The STEAM Journal 1(2).

Ginsburgh VA and Throsby D (2014a) Handbook of the Economics of Art and Culture (Vol. 2). Brussels and Sydney: Elsevier.

Ginsburgh VA and Throsby D (2014b). Creative genius in literature, music and the visual arts. In: Ginsburgh VA and Throsby D (eds) Handbook of the Economics of Art and Culture. 2nd edition.

Gioia D, Corley K and Hamilton A (2012). Seeking qualitative rigor in inductive research: notes on the gioia methodology. Organizational Research Methods 16(1): 15-31.

Gough A (2015) STEM policy and science education: scientistic curriculum and sociopolitical silences. Cultural Studies of Science Education 10(2): 445-458. Doi: 10.1007/s11422014-9590-3.

Granger R and Bazaz P (2018) The Art of Disruption: Creative Learning and Disruption in the Higher Education Sector. Leicester: De Montfort University.

Hale J (2016) Why the Oregon Shakespeare Festival is a really big deal. Available at: https://www.oregonlive.com/performance/ index.ssf/2016/03/why_the_oregon_shakespeare_fes.html (accessed 02 June 2018).

Hardy L (2017) What Does the University's Collaboration with the RSC Offer Students? Available at: http://uobattop.tumblr.com (accessed 14 June 2018).

Haseman B and Jaaniste L (2008) The arts and Australia's national innovation system 1994-2008. CHASS Occasional Papers (No.7).

Hendricks (2015) Can Office Artwork Influence Employee Productivity?, Forbes. Available at: https://www.forbes.com/ sites/drewhendricks/2015/01/12/can-office-artwork-influenceemployee-productivity/\#69a00a811884 (accessed 6 June 2018).

HEFCE Report (2015) Research to Assess the Nature and Annual Value of Student Start-Ups. Available at: http://www.hefce.ac. uk/media/HEFCE 2014/Content/Pubs/Independentresearch/ 2015/Student,Start-Ups/2015_student_start-ups.pdf (accessed 8 December 2018).

HESA (2020). Graduate Outcomes Survey (2017-2018). Available at: www.hesa.ac.uk/data-and-analysis/graduates/ activities (accessed 17 August 2021).

HM Government (2017) Industrial Strategy White Paper: Building a Britain fit for the future. Available at: https://assets.publishing. service.gov.uk/government/uploads/system/uploads/attachment_ data/file/664563/industrial-strategy-white-paper-web-readyversion.pdf (accessed 8 December 2018).
Hurdle J. (2018) These sites no Longer Make Goods. Now They'll Get Them to You Faster. New York Times September 19: 17.

Hesmondhalgh D and Pratt A (2005) Cultural industries and cultural policy. International journal of cultural policy 11(1): 1-14.

Kampfner J (2016) Creative industries are key to UK economy. Available at: https://www.theguardian.com/commentisfree/ 2017/jan/01/creative-industries-key-to-uk-economy (accessed 30 May 2018).

Kebir L and Crevoisier O (2008) Cultural resources and regional development: The case of the cultural legacy of watchmaking. European Planning Studies 16(9): 1189-1205. DOI: 10. 1080/09654310802401607.

Kingston University in Partnership with University Alliance (2017) The Hidden Story. Understanding the Knowledge Exchange Partnership with the Creative Economy. Available at: https://www.hiddenstory.org.uk/downloads/ (accessed 8 December 2018).

Klamer A (2012) Crafting Culture: the importance of craftsmanship for the world of the arts and the economy at large. Rotterdam: Erasmus University of Rotterdam.

Lamla J (2008) Consumer citizen: The constitution of consumer democracy in sociological perspective. German Policy Studies 4(1): 1-34.

Landry C (2012) The creative City: A Toolkit for Urban Innovators. 2nd edition. Routledge.

Liu Y, Ekaterina A and Etzkowitz H (2021) Interdisciplinary Organization as a Fundamental Academic Unit? Industry and Higher Education 35(3): 173-187.

Markusen A (2006) Urban development and the politics of a creative class: Evidence from a study of artists. Environment and Planning A 38(10): 1921-1940.

Misko J (2006) Vocational Education and Training in Australia, the United Kingdom and Germany. Adelaide, SA, Australia: National Centre for Vocational Education Research Ltd.

Muller K, Rammer C and Truby J (2015) A study on effects of knowledge management on organizational entrepreneurship: A case study of educational system. Management Science Letters 2(1): 101-109.

National Endowment for the Arts (2020) The U.S. Arts Economy. Washington, DC: National Endowment for the Arts.

O'Connor J (2007) The Cultural and Creative Industries: A Review of the Literature. London: Creative Partnerships.

O'Connor J and Gu X (2006) A new modernity? The arrival of 'creative industries' in China. International Journal of Cultural Studies 9(3): 271-283.

Pavlakovich-Kochi V and Charney AH (2000) Arts in Tucson's Economy An Economic and Tax Revenue Impact Study of Major Arts Organizations in Metropolitan Tucson. Tucson, AZ: University of Arizona.

Piro J (2010) Going from STEM to STEAM. Education Week 29: 28-29.

Pizzitola L (2002) Hearst Over Hollywood: Power, Passion and Propaganda in the Movies. New York: Columbia University Press. 
Plaza B and Haarich SN (2015) The Guggenheim Museum Bilbao: between regional embeddedness and global networking. European Planning Studies 23(8): 1456-1475.

Potts JD (2009) Creative industries \& Innovation policy. Innovation: Management, Policy and Practice 11: 138-147.

Potts J and Cunningham S (2015) Four models of the creative industries. Revue d'économie Politique 120(1): 163. DOI: 10. 3917/redp.201.0163

Pratt AC (2010) Creative cities: tensions within and between social, cultural and economic development a critical reading of the UK experience. City, Culture and Society 1(1): 13-20.

Redshaw S (2004) The uses of knowledge: collaboration, commercialization, and the driving cultures project. In: Kenway J, Bullen E and Robb S (eds) Innovation and Tradition. The Arts, Humanities and the Knowledge Economy. New York: Peter Lang, 91-100.

Roberts D (2010) Oregon, A Theater Thrives Despite The Downturn. Available at: https://www.npr.org/templates/story/ story.php?storyId=125232977 (accessed 10 June 2018).

RCA (2018) Innovation RCA. Available at: www.rca.ac.uk/ research-innovation/innovationrca (accessed 16 August 2018).

RCA Annual Report, 2016-2017. Available at: https://www.rca.ac. uk/more/about-rca/official-information/corporate-publications/ (accessed 16 August 2018).

RCA Annual Report, 2018-2019. Available at: https://www.rca.ac. uk/more/about-rca/official-information/corporate-publications/ , (accessed 17 August 2021).

Sand G (2009) Letter of George Sand, Volume III (In Three Volumes). New York: Cosimo Inc.

Schatz T (1988) The Genius of the System: Hollywood Filmmaking in the Studio Era. New York: Pantheon.

Simonton DK (2014) Creative genius in literature, music and the visual arts. In: Throsby D and Ginsburgh VA (eds) Handbook of the Economics of Art and Culture (2nd edition). Brussels \& Sydney. 15-42.
Snyder L (2011) The Philosophical Breakfast Club. New York: Random House

Sousa D and Pilecki T (2013) From STEM to STEAM: Using Brain-Compatible Strategies to Integrate the Arts. Corwin Press.

Statista (2018) United Kingdom: distribution of gross domestic product (GDP) across economic sectors from 2006 to 2016. Available at: https://www.statista.com/statistics/270372/ distribution-of-gdp-across- economic-sectors-in-the-unitedkingdom/ (accessed 29 May 2018).

Sandle P (2015) Street artist Banksy's 'Dismaland' is 'escape from mindless escapism. Available at: https://www.reuters.com/article/ us-britain-banksy-themepark-idUKKCN0QP23720150820 (accessed 4 November 2021).

The Kitchen (2018) The Kitchen. History. Available at: http:// thekitchen.org (accessed 10 June 2018).

Tamer M (2009) On the Chopping Block, Again. Ed. Harvard Education Magazine Summer gse.Harvard.edu

Throsby D (1994) The consumption and production arts: of the economics view of cultural. Journal of Economic Literature 32(1): 1-29.

Veselá D and Klimová K (2013) Supporting creative industries with innovative university study programmes. Procedia Social and Behavioral Sciences 81: 152-156.

V and A The Great Exhibition (2018) Available at: http://www. vam.ac.uk/content/articles/t/the-great-exhibition/ (accessed 15 August 2018).

Ware C (1935) Greenwich Village: 1920-1930. Boston: Houghton Mifflin

Weber M (1949) Methodology of the Social Sciences. Glencoe: Free Press

Wolf A (2011) Review of vocational education: 'The Wolf report'. Stationery Office.

Wong H and James R (2017) iPad Pro artists celebrate Urban Sketchers 10th anniversary. Available at: https://www.apple. com/newsroom/2017/11/ipad-pro-artists-celebrate-urbansketchers-10th-anniversary/ (accessed 10 June 2018). 